\title{
A Pentecostal perspective on the use of Psalms of Lament in worship
}

\author{
Leonard P Maré ${ }^{1}$ \\ (University of South Africa)
}

\section{ABSTRACT}

\section{A Pentecostal perspective on the use of Psalms of Lament in worship}

The idea of lament as part of human worship experience is foreign within the Pentecostal tradition. This is the case not only in Pentecostal literature, but also in Pentecostal liturgy. This negative viewpoint regarding the place of lament in worship goes hand in hand with the negativity towards the whole of the Old Testament within the Pentecostal tradition. Pentecostals usually regard the New Testament as more applicable to the life and worship of the Church. This viewpoint is in contrast with Pentecostal hermeneutics, with its emphasis on "shared experience". The aim of this paper is to show that lament should be part and parcel of Pentecostal worship. Guidelines on how lament can be utilised in the Pentecostal Church are presented.

\section{INTRODUCTION}

The use of the Old Testament in Pentecostal churches is evaluated in this paper with reference to current Pentecostal literature as well as the practice within the Church. The problem is addressed on the basis of the following two aspects: the negative regard for the Old Testament in Pentecostal circles, and the neglect of lament in Pentecostal churches ${ }^{2}$. An evaluation of Pentecostal hermeneutics will shed light on the problem by pointing out the deficiencies in this regard within Pentecostal churches. In the end, the aim of this paper is to indicate the importance of the utilisation of the Psalms of lament in Pentecostal churches and to stimulate renewed interest in the Hebrew Bible.

1 Researcher, Research Project on Pentecostalism, Research Institute for Theology and Religion, University of South Africa.

2 It should be noted that this problem is addressed from a white, Western, South-African perspective. Within the denomination to which I belong, this neglect is apparent in theory and practice in this social grouping. 


\section{A NEGATIVE EVALUATION OF THE OLD TESTAMENT}

Pentecostals, generally speaking, tend to hold fairly negative views towards the Old Testament. In a study by Atterbury (1993) he has shown conclusively that the Apostolic Faith Mission of South Africa (the largest Pentecostal denomination in South Africa), does not differentiate between the Old Testament and New Testament on official level, but when one looks at the character and the practice of the AFM, it seems that the New Testament is emphasised at the expense of the Old Testament. Atterbury (1993:103) concludes that the Old Testament has a lower status in the AFM, in spite of various formal comments. He has no doubt that the AFM works with a canon (perhaps canons) within the canon (:106).

This negative viewpoint ${ }^{3}$ with regard to the Old Testament also comes to the fore in the opening address of Burger (1991a) to the $82^{\text {nd }}$ Worker's Council meeting of the AFM on the $1^{\text {st }}$ of April 1991. In this address and in a series of articles in the "Pinksterboodskapper" (Pentecostal Messenger), the official monthly periodical of the AFM (1991), Burger, who is the president of the AFM, emphasised the AFM's view of the Bible. He is of the opinion that Christ is the centre of everything (1991b:2). Therefore Christ is also the centre of the Scriptures. This means that He is also the focal point of the Old Testament. The Old Testament loses its meaning and significance if one does not see Christ in it. Jesus Christ is the focus of the Old Testament and the Old Testament has to be understood in Him and interpreted in Him (1991b:3). According to Burger the Old Testament is only relevant as long as it is understood in Christ.

According to Burger, when the Old Testament is not understood in Christ, it becomes a book that is a source of delusion and heresy to many. If it is not read and interpreted Christologically, the Old Testament can be abused by anyone who wants to teach any ideology (1991b:3). Burger (1991b:6) goes so far as to say that the Old Testament receives its qualification and name as Word of God in

3 Burger's Christological reading of the Old Testament results in an interpretation of the Old Testament where it loses its significance and relevance unless it is understood in Christ. This, to my mind, indicates a negative view of the Hebrew Bible as Scripture in its own right. 
that Christ can be seen in the Old Testament. "If you take Christ out of the Old Testament then I have to question whether it can still be called the Word of God” (translated).

Due to its nature, the latter statement poses unending problems. A large part of the Old Testament says nothing about Christ. This would mean that a large part of the Old Testament could no longer be viewed as canonical. The problem inherent in this comment of Burger lies in the fact that he makes himself guilty of a forced reading of Christ into the Old Testament. Christ is of course the centre of our lives and theology, but this does not mean that He is "hidden" in every Old Testament text.

This view of the inferior position of the Old Testament inevitably influences the way in which worship in the Old Testament, and thus also in the worship of the Church and the individual believer, is seen. Burger (1991e:2) states very clearly that the liturgy of the Pentecostal Church must be validated in the New Testament. According to him, Christ and the New Testament is the canon of our liturgy (1991a). The worship practices of the Old Testament should primarily be understood as part of the sociocultural background of the Old Testament, and can only be practiced in the Church today, if the same practices are found in the New Testament.

It is interesting that Burger attributes certain liturgical actions in the Old Testament to socio-cultural factors, but he does not comment on the cultural constraints of the New Testament liturgical and worship practices. The problem resulting from this is that he accepts the New Testament as prescriptive for worship, but the Old Testament prescriptions are labeled as cultural customs. In fact, the reality is that we find the same customs in the New Testament as in the Old Testament and that the New Testament pattern of worship can also be described in socio-cultural terms. The Scriptures that both Jesus and the early Church used, were those Old Testament books that were already accepted as canonical.

In contrast to Burger's point of view, Segler and Bradley (1996:21) point out that worship in the New Testament is the same in character as in the Old Testament. The roots of Christian worship can be found in Jewish worship practices. The first Christians were Jews who still went to the temple and the synagogue and followed the Jewish liturgical forms and sung Jewish hymns (cf Coetzee 
1993:13; Wilson-Dickson 1992:16, 24, 25). It is not credible to maintain that all worship practices changed all of a sudden after the coming of Christ.

Jesus supported the worship practices of Israel and followed them. An investigation into his attitude towards the temple, the synagogue and the festivals of Israel, confirms this (Webber 1994:42). Further support for this point of view is found in Gentile (1994:3-4): "The worship forms found in the book of Psalms provided an ideal way for the lively, Spirit-filled Christians of Bible days to express themselves in personal and corporate worship".

Minnaar (1983:2-5) also values the New Testament above the Old Testament as a source of worship: "Their worship, as beautiful and sincere as it was, was rooted in the Old Testament. But what of us? We live in the New Testament promise ... How much more glorious is the New Testament source of worship" (translated). Yet Minnaar uses the "inferior source" in order to illustrate his thoughts on worship. He uses Psalm 95 as "guideline on the nature of worship and how to practice it" (1983:3 - translated). This is a very inconsistent handling of the Old Testament.

Malm (1988:2) describes Old Testament worship as the shadow of New Testament reality: “... the physical activities involved in Old Testament worship ... were a shadow of the reality of worship that was to be revealed through Jesus Christ”. Malm has the same point of view as Burger, namely that the New Testament "fulfilment" legitimises the use of the Old Testament. This kind of interpretation, that regards the Old Testament merely as "shadow", and the New Testament as the reality, denies the historical character of the Old Testament. This would mean that the Old Testament had no message if it only received its theological meaning in the New Testament (which would be the logical conclusion of Burger's reasoning). The Old Testament did have meaning and definitely was Word of God before Christ appeared and still is today.

\section{THE PLACE OF LAMENT IN PENTECOSTAL WORSHIP}

Those writing from a Pentecostal perspective state unequivocally that lament does not belong in Christian worship. Law (1987:83) writes as follows about Jesus: "He will only bring our confession of the Word to the Father. He will not bring our begging and our crying and our pleading”. Taylor (1985:62-64) also allows no place for 
lament in Pentecostal worship. He maintains that one should bring praise to God in all circumstances.

This negative view with regard to lament is not only apparent in Pentecostal literature, but is also clearly present in practice. In the liturgy of Pentecostal churches there is virtually no room for lament. It is a fact that someone might attend a Pentecostal service and leave thinking that Pentecostals' lives are free from any kind of negativity or disharmony. Pentecostals tend to reject any expression of feelings of negativity, anger, revenge and complaint as a legitimate part of worship. This situation, to my mind, is an impoverishment of the full spectrum of human worship before God. The Psalms give clear evidence of humans also bringing their complaints to God in worship. The reason for this rejection of lament in Pentecostal circles probably correlate with the negative rating of the Old Testament in the Pentecostal Church.

Westermann (1977:5) argues cogently that praise and lament ought to be part of the believer's worship. Praise and lament are the two poles around which human life experiences revolve: "Das Gottelob ist zu Wort kommende Daseinsfreude, ... die Klage ist zu Wort kommendes Leid. Als Sprache der Freude und Sprache des Leides gehören Lob und Klage zusammen als Äusserungen des Menscheins im Gegenüber zu Gott”.

Experiences of pain and suffering and heartache are inextricably part of human existence. There is a direct connection between the "experience of dislocation in which we all share and lament psalm of Israel" (Brueggemann 1986:21). The psalms of lamentation speak of a lifestyle in which we have the right and privilege to bring our pain and heartache to God, where we may express our feelings and experiences of negativity as part of our worship. Brueggemann (1984:11) is correct when he writes "much Christian piety and spirituality is romantic and unreal in its positiveness". To think that the Christian life (even for Pentecostals!) is free from pain and suffering "not only ignores the Psalms but it is a lie in terms of our experience" (1984:11). It is therefore an illusion to think that one can have a relationship with God in which only praise is present and not also lament. Surely it is unrealistic to believe that there is room only for praise in Pentecostal worship but not for lament. 
Why does the Church ignore lament? Is it "an evangelical defiance guided by faith" or is it rather "a frightened, numb denial and deception that does not want to acknowledge or experience the disorientation of life" (Brueggemann 1984:51)? It is strange that Pentecostals, who place a very high premium on the authority of the Bible, and who are very enthusiastic in their use of the Bible, ignore the psalms of lament which express experiences of pain, misery and suffering in life. Yet again, this illustrates the selective way in which Pentecostals use the Bible. Brueggemann (1984:52) rightly observes that "a church that goes on singing 'happy songs' in the face of raw reality is doing something very different from what the Bible itself does”.

The Pentecostal Church does not use the psalms of lamentation because it would be regarded as an expression of unbelief. Pentecostals tend to believe that faith means not to acknowledge negatives. They believe that faith is a positive confession in the face of pain and suffering, of negative experiences and emotions. To my mind, true faith acknowledges that pain and suffering are present in the lives of believers. Furthermore, true faith wants to admit that all our experiences, negative as well as positive, have to be brought under the sovereignty of a loving God who cares and is interested in every aspect of our existence, a God who Himself is familiar with pain and suffering through the cross of our Lord, Jesus Christ.

The use of the psalms of lamentation in worship is an act of bold faith because it does not pretend that life is free from pain and suffering. Furthermore it acknowledges that there is nothing that does not belong in our dialogue with God and that all our experiences and feelings of negativity may be expressed to God as an integral part of our worship.

There is nothing out of bounds, nothing precluded or inappropriate. Everything properly belongs in this conversation of the heart. To withhold parts of that conversation is in fact to withhold parts of life from the sovereignty of God. Thus these psalms make the important connection: everything must be brought to speech, and everything brought to speech must be addressed to God, who is the final reference for all of life. 


\section{PENTECOSTAL HERMENEUTICS AND THE USE OF LAMENT $^{4}$}

The neglect of lament in worship is in sharp contrast with the nature of Pentecostal hermeneutics. Pentecostals have a unique way in which they work with the Bible. The uniqueness of Pentecostal theology and hermeneutics can not be doubted (Mclean 1984:38). The Bible fills a central position in the worldview of Pentecostals. They regard the Bible as a living book in which the Holy Spirit is always actively working. The Bible is regarded as the Word of God and therefore God can be encountered in the pages of the Bible (Ellington 2001:245; Johns 1995:90). Ahn (2000:25) points out that Pentecostals find their identity in their distinctive reading of the Bible coupled with their understanding of the on-going activity of God in the Holy Spirit. This means that Pentecostals not only focus on the activities of God through his Spirit in the world of the Bible, but they also believe that these activities continue to this day (cf also Lewis 2000:109-112).

For Pentecostals, this view of the Bible as the Word of God is not merely a dogmatic statement, but it is based on their personal experience of God in their lives (this point will be discussed in more detail later). Ellington (1996:17) confirms this thought as follows:

Pentecostals do not found their understanding of the authority of Scripture on a bedrock of doctrine, but ... their doctrine is itself resting on something more fundamental, dynamic, and resilient; their experiences of encountering a living God, directly and personally.

However, it is unfortunate that this positive view of the Bible is applied selectively. It has already been pointed out in 1.2 that in practice Pentecostals tend to value the New Testament more than the Old Testament. This, however, is a position that is contrary to the character of Pentecostal hermeneutics. The central position that the Bible fulfills in Pentecostal hermeneutics ought to be applicable to both the Old- and the New Testament.

4 This short discussion is not meant to be read as a comprehensive treatment of the subject of Pentecostal hermeneutics. I only highlight a few characteristics of Pentecostal hermeneutics that are relevant for the present study. For a comprehensive treatment of the subject, cf Noel (2007:84-156, 195-272). 
Pentecostals also acknowledge that God still speaks today just as in Biblical times (Mclean 1984:46). The authors of the Bible "are a witness to their concrete historical relations with God, the positive history upon which their writings are founded, a positive history and concrete relationship which we claim continues on today with no ontological break between God's activity then and now" (:46).This means that Pentecostals not only emphasise that God still does the same that He has done in Biblical times, but also that the experiences of believers ought to be similar to that of people in Biblical times. Pentecostals expect that all supernatural manifestations mentioned in the Bible should still take place today (Ahn 2000:26; Archer 1996:66; Ellington 2001:245).

For Pentecostals this means that the task of interpretation is never completed before the contemporary meaning of the text has been established". "To put it another way, the interpreter must not only answer the question: What did it mean?, but also the question: What does it mean?” (Arrington 1994:103). Hermeneutics that focuses "only upon what the original inspired author meant and/or intended first readers to understand will not completely satisfy the requirements of a Pentecostal hermeneutics" (Archer 1996:75). Establishing the meaning of a text in its historical context does not solve the problems of interpretation. Actualization of the meaning for modern times and socio-cultural circumstances has to take place (Menzies 1994:118).

Lewis (2000:115) argues in a similar vein when he writes that the process of doing hermeneutics is not finished until the biblical text "is taken from the there and then, and 'fleshed out' within the here and now". Ahn (2000:46) therefore rightly argues that the Pentecostal "experience verified interpretation in their practice of hermeneutic" is interested in "reader-effects of the biblical texts". The work of exegesis can thus only be finalised when the modern day reader, experiencing the presence of the Holy Spirit in the process of interpretation, has recaptured the meaning of the biblical text.

The essence of Pentecostalism strongly claims that the supernatural spiritual experience of Biblical characters is a possibility for modern day believers. "Biblical interpretation requires

5 This hermeneutical principle is of course true for other traditions as well. 
a theory and method of hermeneutics that enhances a reexperiencing of the Biblical text” (Arrington 1994:105). Macchia (2000:54-55) maintains that Pentecostals do not regard the experience of the Apostles as different in kind or in degree from what Christians of all generations can experience. In the end Pentecostals believe that the same Spirit who worked in the Bible, and specifically in the Book of Acts, is still involved in the lives of believers to make the events and words of the biblical text alive among us (cf also Lewis 2000:103-105). Mckay (1994:26) therefore calls the Pentecostal approach to understanding the Bible "a theology of biblical experience - or perhaps better - 'shared experience'”. This aspect is very important for Pentecostals - a shared experience of God and his miraculous power with the people who lived in Biblical times.

A general contention against Pentecostals is that they overemphasise experience and that they read their own experiences into the text. Unfortunately it is a fact that this criticism is often the truth. However, this is not as it should be. There ought to be a continual interaction between the experience of the believer and the Word. Arrington (1994:106) formulates it as follows:

... the hermeneutic process can be viewed as dialogic rather than linear, so that, at every point, experience informs the process of interpretation and that the fruit of interpretation informs experience. So Pentecostals admit that their praxis informs what they find in Scripture and they go on to acknowledge that what they find in Scripture informs their Pentecostal praxis.

The experience of Pentecostals ought not to be regarded merely as the final element in theology and hermeneutics. The Pentecostal experience does fulfil a verification function, but it is an incomplete description of the position filled by experience in Pentecostal hermeneutics. Experience already plays a role at the beginning of the hermeneutic process, in other words, as presupposition and not only as verification (Stronstad 1992:16).

The "spectacles" through which the text is read, play a definite role in the interpretation of the text. It is the role that can be allocated to experience in the interpretation process. Stronstad (1992:17) expresses it as follows: 
... my thesis is that charismatic experience in particular and spiritual experience in general gives the interpreter of relevant biblical texts an experiential presupposition which transcends the rational or cognitive presuppositions of scientific exegesis. Furthermore, this charismatic experience results in an understanding, empathy, and sensitivity to the text, and priorities in relation to the text which other interpreters do not and can not have.

It is of course true that all believers and not only Pentecostals bring their faith experiences to the text. Everybody who reads the Bible reads it with "tinted glasses". We all should be careful not to read our presuppositions of experience into the text, in order not to be misled by it.

The point of departure for this paper is that this Pentecostal emphasis on experience should be extended so that it does not only refer to the supernatural, charismatic experiences of Acts (and the rest of the New Testament). This hermeneutical principle also creates room for the fact that $21^{\text {st }}$ century Pentecostal believers can and do share in the experiences of the Old Testament believers being experiences with God as expressed in the Old Testament, specifically the Psalms, whether they are positive or negative.

\section{POTENTIAL APPLICABILITY OF THE PSALMS OF LAMENT IN THE PENTECOSTAL CHURCH}

\subsection{The Psalms as God's Word and humanity's answer}

The Psalms should have an important place in the worship life of the Pentecostal Church. Neglecting the Psalms in worship, leads to an impoverishment of every Pentecostal's relationship with God.

On the one hand, the Psalms should be understood as God's Word to us, on the other hand the Psalms are believers' answer to the voice of God in their lives (cf Coetzee 1993:8). It is part of God's written Word and as such it communicates the will of God to the believer. We also find in the Psalms the expression of the believers' experiences in life, both positive and negative. The believers' testimony concerning the greatness and goodness of God is contained therein, but also their struggle with God when there is a conflict between their theology and their experience.

God wants to transform our minds and deeds by the power of his Word. The neglect of the Psalms means that this part of God's 
message in the Bible is not involved in this transformation process. The Psalms illustrate our "living with God" in an exceptional manner. Therefore, we dare not ignore them.

The hermeneutical principle of "shared experience" makes the neglect of the psalms an incomprehensible, untenable mystery. There is surely no other book in the Bible that gives expression with such intensity to the experiences and emotions of believers in their relationship with God. The psalms speak of a way of life in which our relationship with God permeates every aspect of our lives. It speaks of a relationship with God in which all of our emotions and experiences are brought under the sovereignty of God. In exactly the same way as the psalmists, Pentecostal believers experience the greatness and goodness of God, but also have experiences of pain and suffering in their lives. If Pentecostals are to be true to their own Pentecostal hermeneutical principles, the psalms dare not be ignored, but they must be utilised as expressions of believers' deepest emotions and experiences of God, both positive and negative.

The most significant shortcoming with regard to the neglect of the psalms and the attendant impoverishment of our worship experience, come to the fore in the psalms of lament. Pentecostals tend to believe that Christians should not lament, but that they should always be positive, whatever the circumstances may be. To lament would be a sign of doubt and unbelief, therefore prayer should always be positive, because that is all that God wants to hear.

This kind of theology means that lament is almost never used in Pentecostal worship. This leads to dishonesty in peoples' relationship with God. Instead of giving utterance to their negative emotions and experiences with intensity, Pentecostals try to hide their feelings of rage, pain, suffering, anxiety, fear and revenge from God, thereby putting on a veil of hypocrisy with which they think we are pleasing God. They think that they can hide these emotions from God by uttering empty words of positiveness, while their hearts are seething with dismay. They are only misleading themselves, because God, who sees the unseen, knows every emotion and feeling that is churning their innermost beings. He wants his followers to be honest with Him because there is nothing out of bounds in our dialogue with Him, instead of trying to deceive Him with our feigned piety.

The fact is that Pentecostals have experiences similar to people in Biblical (Old Testament) times. This shared experience is included 
completely within Pentecostal hermeneutics. If Pentecostals are to take their own hermeneutics seriously, they should utilise the psalms of lament as expression of their negative experiences of life.

\subsection{Reasons for lament in the Psalms}

For the purpose of our further discussion, some of the results of an intensive study of five psalms of lament, namely Psalms 13, 22, 44, 58 and 137, are briefly discussed (cf Maré 1998:154-270). The purpose is to ascertain what led to lament in the lives of the psalmists, and how similar experiences still play a role today in the lives of Pentecostal believers and their relationship with God.

\subsubsection{God hides his face}

One of the most important reasons for lament in the Psalms is the fact that God hides his face (Pss 13; 22; 44). God who hides his face or the accusation that $\mathrm{He}$ has forgotten the psalmist, is not an indication of a totally absent God, but should be understood from the perspective of the poets. Due to certain circumstances in their lives, they experience God as absent in their lives. In an intensive study of these psalms (cf Maré 1998:154-270), it was clear that a personal relationship with God was presupposed. Only those who have an intimate, personal, honest relationship with the Lord, have the right and privilege to lament.

\subsubsection{God casts off Israel and brings them to shame}

While the hidden face of God can be described as a passive rejection of his people, we find in Psalm 44 an example of God actively rejecting Israel. This is in contrast to the love of God for the people. Instead of God protecting his people in accordance with his loyalty under the covenant relationship, He delivers them to their enemies. The innocence of the people and God's faithfulness to the covenant, motivate the people to lament against God, to God. This lament of the people against God to God indicates that they believed that He is in control of everything, both positive and negative.

\subsubsection{God sleeps}

A third accusation leveled against God, is that He sleeps (Pss 44:10 et seq). This should be understood as the perception of the psalmists of their situation (cf Ps 121:4 where the psalmist claims that God never sleeps). God's apparent lack of interest causes him to think that perhaps God has fallen asleep. Although this might seem like heresy, the point is that the poets articulate their experiences of 
God's lack of interest in their lives honestly in anthropomorphic language.

\subsubsection{The threat of enemies}

In Psalms 13, 22, 44, 58 and 137 the threat of enemies is an important reason for lament. The absence of God in the life of the poet is one of the reasons why the enemy is triumphant (Ps 13). The threat of enemies is described in beautiful metaphorical language. The identity of the enemies is never revealed (Ps 137 is an exception). The psalmists use stereotyped language to describe the enemies. Thus the category "enemy" is left "open". This means that anybody can recognise their enemies (or problems) in this general description.

\subsubsection{Rulers who abuse their authority}

Rulers who abuse their authority so that justice is miscarried is a further reason for lament in the psalms (Ps 58). Believers are also oppressed and exploited and the only recourse they then have is to lament to God. The reason in this instance is that God is the only one who can see to it that justice is done.

\subsubsection{Innocence}

The poets sometimes plead their innocence in the face of trouble and rejection (Ps 44). This means that suffering in the life of the believer should not always be ascribed to sin and guilt in a Christian's life. Many Pentecostals and Charismatics tend to attribute suffering to sin in the life of the believer. Although that may be the case in some instances, it should not be generalised. It often happens that believers experience trouble and suffering through no fault of their own, and they may then maintain their innocence before God.

\subsubsection{The threat of death}

The threat of death is another reason for lament in the Psalms (Ps 13). It must be emphasised that the understanding of death in the Old Testament is a much more complex matter than the modern interpretation often allows. In the Psalms, life and death are described in terms of the believer's relationship with God. The sphere of death raises its head on earth whenever we experience sickness or suffering or trouble. Death is understood as separation from God, not necessarily as physical death. The only course of action then available to believers is to pour out their hearts to God. 


\subsubsection{Impatience and anxiety as expression of emotions}

The authors of the psalms of lament also experience different emotions in times of distress and misery. Impatience and anxiety are emotions that come to the fore in times of trouble (Ps 13). The hidden face of God is indicated as the reason for the psalmist's impatience and anxiety. Yahweh is brought to court and He is accused of being responsible. It is striking that the poets do not try to hide these feelings from God, but they verbalise them openly and honestly.

\subsubsection{Utterances of revenge and retribution}

Utterances of revenge and retribution reflect strong emotions in the psalms of lament (Pss 58, 137). The fact is that those emotions are similar to what believers sometimes experience in their hearts, especially in a country like South Africa where crime is rampant. What do Christians do with these kinds of emotions? Should they take revenge? Do they take up arms and exact vengeance? The answer is no. Christians do not take the law into their own hands, although that might be the way they feel. Believers take their feelings of vengeance seriously, by using the only weapon they have available: their words. They go to God and tell Him what they feel and think. By doing so, they release their feelings of revenge and retribution into the hands of God, to whom alone vengeance belongs. In this way, believers are set free from their desire for revenge and the exacting of vengeance is left in the hands of the righteous God.

\subsubsection{Sorrow}

The poets of the psalms of lament also exhibit sorrow as an emotion (Ps 137). Israel's sorrow is due to the fact that they have been separated from Zion. Due to their distress it was not possible for them to sing a song of Zion, a song of gladness. Their hearts were being torn asunder by their sorrow; therefore joy was an impossible option. This illustrates the principle that different circumstances allow for different experiences of worship. In times of distress, worship means pouring out one's pain and anguish before God.

\subsubsection{Trust}

The confession of trust in the psalms of lament should be understood against the background of God's dealings with the forefathers and the believer in the past (Pss 13; 22; 44). God is actively involved in history and in the lives of his people. The psalmists have come to know God as trustworthy in countless situations. He is a God who 
saves and helps, when He is called upon. They can confess their trust, because He has proved Himself to be trustworthy. The saving acts of God are directly connected to his dominion (Ps 22). He can save and deliver his people from distress; He is trustworthy, because He rules. God's saving acts also have an evangelical function (Ps 22). When people see the saving acts of God on behalf of the believer, they will have to acknowledge that He alone is Lord and King (Ps 22).

\subsubsection{Joy}

The psalms of lament end almost always not with lamentation, but with joy and praise. The palms of lament eventually adopt a positive tone, and the psalmists, because of their trust in God, praise Him with gladness. To my mind, this change of mood should be attributed to the dictates of God in the heart of the poet. In Pentecostal terms, one would say that the psalmist has "prayed through". Joy is also apparent when God brings his salvation (Ps 13). When the psalmists have been assured in their hearts that God has heard them, that He has listened to their lament and that He will answer them, they start praising God (Pss 13; 22; 44). God does not hide Himself any more; He has revealed Himself to the one praying. It is important to note that the praise offered to God in the psalms of lament is offered in the midst of crisis. At this stage, the circumstances of the psalmists have not changed, but they give praise to God in advance for that which the Lord is going to accomplish in their lives. It is just as important to note that praise in the psalms of lament was given birth through the lament of the psalmist. Praise follows lament. Pentecostals, who teach that praise should always be offered to God, regardless of the circumstances, because God does not listen to lament, are hereby proven wrong. Lament is just as acceptable to God as praise. He listens to expressions of pain and anger, He cares, and He changes lament into praise.

In two instances there is a connection between the joy of the psalmist and retribution (Pss 58; 137). Christians may express gladness when they see that justice and righteousness prevail. 


\subsection{Applicability of the Psalms of Lament in the Pentecostal Church}

The psalms of lament can be utilised in different ways in the Church.

\subsubsection{Liturgical}

The psalms of lament can be utilised in the liturgy to verbalise the distress that people experience. Christians do experience pain, sorrow, anxiety, doubt, fear, anger, and feelings of revenge and retribution. The believer should not try to hide these emotions from God, but one should tell it to Him in all honesty. This can be done as a part of liturgy. Jesus Himself verbalised his negative emotions, and his example can surely be followed. Worship without lament, impoverishes worship. Although it is true that verbalising pain and sorrow and expressing negative feelings and experiences make one feel uncomfortable, it should be part of Christian worship. It speaks of honesty and openness in one's relationship with God.

\subsubsection{Didactic-homiletical}

The psalms of lament can also be used in a didactic-homiletical manner to teach on the correct way in which these psalms can be applied in our walk with God. It should be taught from pulpits and in seminaries that it is acceptable to God that his children lament to Him. Our deepest emotions and feelings should not be hidden from Him. In times of crises, the Christian response should be to lament to God, not lament for the sake of lament, but lament in order for God to change us, as well as our circumstances. Jesus Himself used a psalm of lament on the cross (Ps 22), not a song of praise. It is important that Christians should be taught that God wants them to be totally honest with Him.

\subsubsection{In prayer}

The psalms of lament can also be used as part of personal times of prayer. It is there, when believers are alone with God, that they should voice their innermost feelings and emotions to Him. When Christians dialogue with God, nothing should be hidden from Him. They must be completely honest with Him and not try to impress Him with false piety. Nothing is out of bounds in one's private conversation with God.

\subsubsection{In pastoral counseling}

The psalms of lament can be used very fruitfully in pastoral counselling. There are so many people that are broken inside due to 
a variety of problems. Children who are sexually abused by parents, women who are raped, people who are victims of violent crime, the death of a loved one, sickness, pain and sorrow are part and parcel of the terrible reality of a broken world. The Church has such an important role to play in this regard. In counselling, the victim should be helped and given the opportunity to honestly voice his or her emotions. Restoration and forgiveness is only possible when the emotions and feelings that people experience in times of crises have been taken seriously. The psalms of lament can be appropriated to verbalise those experiences.

\subsubsection{Prophetical function}

One of the psalms of lament that was researched can also fulfil a prophetic function (Ps 58). Leaders should be addressed when corruption and injustice take place. They should know that there is a God who sees and who will not let them get away with abusing their positions of power.

\section{CONCLUSION}

The psalms can be a wonderful source for all aspects of worship. The fact that the psalms are used selectively impoverishes our worship experience. This neglect of the psalms contradicts Pentecostal hermeneutics. Pentecostals have similar experiences, both positive and negative, to Old Testament believers. Depending on the situation, believers can find something in the psalms to give voice to the totality of their experiences.

The reasons given above for the use of lament in ancient Israel are experiences and emotions that Pentecostals experience as well. They do not experience prosperity all the time. They also feel as if God has abandoned them, and danger, sickness and death threaten them as well. The psalms of lament are a great source to verbalise negative feelings and experiences to God in worship. In the end, Pentecostals should make a paradigm shift with regard to their view of the Old Testament, so that the Old Testament can take its rightful place, alongside the New Testament, as the Word of God.

\section{Consulted literature}

Ahn, Y J 2000. Various debates in the contemporary Pentecostal Hermeneutics. The Spirit \& Church 2 (1), 19-52.

Archer, K J 1996. Pentecostal Hermeneutics: retrospect and prospect. JPT 8, 6381. 
Arrington, F L 1994. The use of the Bible by Pentecostals. Pneuma 16 (1), 101107.

Atterbury, V 1993. 'n Analise van die skrifbeskouing van die Apostoliese Geloof Sending van Suid-Afrika, met spesifieke verwysing na die hantering van die Ou Testament. M A dissertation, University of Port Elizabeth.

Brueggemann, W 1984. The message of the Psalms. Minneapolis: Augsburg.

-, 1986. Praying the Psalms. Winona: St Mary’s Press.

Burger, I 1991a. Openingsrede by 1991 Werkersraad. Kasetbandopname. Johannesburg: Gospel Publishers.

-, 1991b. Christus die middelpunt, deel 1. Pinksterboodskapper 16(6), 2-6.

-, 1991c. Christus die middelpunt, deel 2. Pinksterboodskapper 16(7), 2-4.

-, 1991d. Christus die middelpunt, deel 3. Pinksterboodskapper 16(8), 2-3.

-, 1991e. Christus die middelpunt, deel 4. Pinksterboodskapper 16(9), 2-3.

Coetzee, J H 1993. Die Psalms - Woord en antwoord. SK 14(1), 8-19.

Ellington, S A 1996. Pentecostalism and the authority of Scripture. JPT 9, 16-38.

-, A 2001. History, story and testimony: Locating ttruth in a Pentecostal Hermeneutic. Pneuma 23 (2), 245-263.

Gentile, E B 1994. Worship God! Exploring the dynamics of Psalmic worship. Portland: Bible Temple Publishing.

Johns, J D 1995. Pentecostals and the postmodern worldview. JPT 7, 73-96.

Law, T 1987. Praise releases faith. Tulsa: Victory House.

Lewis, P W 2000. Towards a Pentecostal Epistemology: The role of experience in Pentecostal Hermeneutics. The Spirit \& Church 2 (1), 95-125.

Macchia, F D 2000. The Spirit and the text: Recent trends in Pentecostal Hermeneutics. The Spirit \& Church 2 (1), 53-65.

Malm, R F 1988. Perfected praise: Leading children into meaningful worship. Shippensburg: Destiny Image.

Maré, L P 1998. ' $n$ Kritiese beoordeling van die gebruik van die Psalms in die Pinksterkerk. D Litt et Phil thesis, Rand Afrikaans University.

McKay, J 1994. When the veil is taken away: The impact of prophetic experience on biblical interpretation. JPT 5, 17-40.

Mclean, M D 1984. Toward a Pentecostal Hermeneutic. Pneuma 6 (2), 35-56.

Menzies, R P 1994. Jumping off the postmodern bandwagon. Pneuma 16 (1), 115-120.

Minnaar, P A 1983. Aanbidding. Pinksterboodskapper 8 (9), 2-5.

Noel, B T 2007. Pentecostal and postmodern hermeneutics: Comparisons and contemporary impact. D Th thesis, UNISA.

Segler, F M \& Bradley, R 1996. Understanding, preparing for, and practicing Christain worship. Nashville: Broadman \& Holman. 
Stronstad, R 1992. Pentecostal experience and hermeneutics. Paraclete 26 (1), 14-30.

Taylor, J R 1985. The Hallelujah factor: The principles and practice of praise. Crowborough: Highland books.

Webber, R E 1994. Worship old and New. Grand Rapids: Zondervan.

Westermann, C 1977. Lob und Klage in den Psalmen. Göttingen: Vandenhoeck \& Ruprecht.

Wilson-Dickson, A 1992. The story of Christian music. Oxford: Lion. 